\title{
Pelaksanaan Cluster Learning System di Masa Pandemi Covid-19 di Sekolah 3 T
}

\author{
${ }^{1}$ Sunarto, ${ }^{2}$ Zulfikar \\ ${ }^{1}$ SMP Negeri 7 Budong-budong, Mamuju Tengah \\ e-mail: sunarto.ind@gmail.com
}

\begin{abstract}
This study aims to determine the implementation of the Cluster Learning System during the Covid-19 pandemic in rural schools. This research was conducted at SMP Negeri 7 Budong-Budong. Geographically this school is located in Mamuju Tengah District, West Sulawesi Province. Central Mamuju Regency is one of the underdeveloped districts in Indonesia. This study used a qualitative approach to describe the implementation of the Cluster Learning System during the Covid-19 pandemic in rural schools. Data obtained through observation, interview, and documentation study techniques.

Meanwhile, the data analysis process used data analysis techniques proposed by Miles and Hubermen, which consisted of three activity lines: data reduction, data presentation, and conclusion drawing. The research results found that in implementing the Cluster Learning System, there were three stages carried out by the SMP Negeri 7 Budong-Budong, namely the planning, implementation, and evaluation stages. In addition, in the application of the Cluster Learning System at SMP Negeri 7 Budong, there are several advantages and disadvantages.
\end{abstract}

Keywords: cluster learning system, covid-19 pandemic, 3T (1) Licensees may copy, distribute, display and perform the work and make derivative works and remixes based on it only if they give the author or
licensor the credits (attribution) in the manner specified by these. Licensees may copy, distribute, display, and perform the work and make derivative works and remixes based on it only for non-commercial purposes.

\section{PENDAHLUAN}

Beberapa Negara di dunia dikejutkan oleh merebaknya virus Covid-19 yang begitu cepat. Virus ini ditengarai bermula dari kota Wuhan, (Chen et al., 2020). Virus ini menjadi ancaman tersendiri bagi warga negara di dunia karena berujung pada kematian. Selain itu, virus ini dinyatakan sebagai bencana non-alam (Chih-Cheng Lai , Tzu-Ping Shih, Wen-Chien Ko, Hung-Jen Tang, 2020). Tentunya penyebaran virus ini secara tidak langsung berdampak pada berbagai bidang, salah satunya adalah bidang pendidikan. Menurut data yang dirilis pada tanggal 18 Maret 2020 oleh United Nations Educational, Scietific and Cultural Organization (UNESCO) melaporkan ada 112 negara yang sudah menerapkan strategi pembelajaran jarak jauh sebagai solusi di bidang pendidikan (Yulianingsih et al., 2020).

Melihat kondisi seperti ini, pemerintah bertindak cepat untuk mencegah penyebaran virus corona di bidang pendidikan. Salah satu tindakan yang dianggap strategis yaitu dikeluarkannya surat edaran nomor 4 tahun 2020 tentang Pelaksanaan Kebijakan Pendidikan dalam Masa Darurat Penyebaran Covid-19 oleh Menteri Pendidikan dan Kebudayaan. Regulasi ini menjadi dasar bagi satuan pendidikan untuk melakukan proses layanan pendidikan. Dalam surat edaran ini berisi beberapa instruksi tentang: 1) Pelaksanaan Ujian Nasional (UN); 2) Proses Belajar Dari Rumah (BDR); 3) pelaksanaan Ujian Sekolah (US) dan kelulusan; 4) Proses kenaikan kelas; 5) Tata cara Penerimaan Peserta Didik Baru (PPDB); 6) Pengelolaan 
Dana Bantuan Operasional Sekolah (Kemendikbud, 2020b).

Tentunya kebijakan ini menjadi salah satu acuan yang dapat diperhatikan oleh sekolah dalam melakukan layanan pendidikan di masa pandemi Covid-19 khususnya pada proses belajar mengajar. Instruksi untuk melakukan Pembelajaran Jarak Jauh (PJJ) atau dengan kata lain Belajar Dari Rumah (BDR) mulai digiatkan oleh sekolah yang ada di Indonesia mulai dari Sabang sampai Merauke. Pada prinsipnya kegiatan belajar dari rumah adalah upaya untuk mempermudah peserta didik mendapatkan pembelajaran dari guru meskipun peserta didik tetap berada di rumah masing-masing. Untuk itu, para guru harus menyiapkan strategi untuk memberikan akses materi pembelajaran tanpa batasan waktu dan tempat selama masa Covid-19 (Kurniasari et al., 2020). Dalam metode pelaksanaan pembelajaran jarak jauh dikenal dengan dua jenis cara yaitu dalam jaringan (daring) dan luar jaringan (luring) (Dormalin et al., 2020). Menurut (Selvi Loviana, 2020) pembelajaran daring merupakan interaksi antara pendidik dan peserta didik dalam kegiatan belajar mengajar dengan menggunakan fasilitas koneksi internet sehingga tidak terjadi kontak fisik.

Namun pembelajaran dengan sistem belajar dari rumah dengan sistem daring bukannya tanpa hambatan. Ada beberapa kendala yang sering dikeluhkan oleh para pendidik maupun peserta didik diantaranya para pendidik kurang menguasai teknologi, pembelajaran membosankan, tingginya biaya pembelajaran dalam jaringan karena harus mengeluarkan biaya tambahan untuk membeli paket internet dan masih banyak kendala yang dihadapi dalam pembelajaran dalam jaringan di masa Covid-19.

Sekolah yang paling merasakan sulitnya pembelajaran daring adalah sekolah yang berada di daerah tertinggal, terluar dan terdepan (3T). Sudah menjadi rahasia umum sulitnya akses atau sarana dan prasarana di daerah 3T.

Sarana dan prasarana di sekolah 3T sangat minim, ketika harus menyesuaikan pembelajaran secara daring tentunya dirasa tidak tepat. Hal ini disebabkan karena beberapa sekolah di daerah 3T masih banyak yang belum memiliki listrik, akses jaringan, apalagi jika siswa harus memiliki smartphone ataupun laptop. Tentu hal ini akan menambah permasalahan pengajaran di daerah $3 \mathrm{~T}$.

Untuk itu, pihak sekolah di daerah 3T harus mencari strategi lain agar proses pembelajaran berjalan lebih maksimal dengan melihat kondisi yang ada di wilayah masingmasing. Dengan kondisi seperti ini, salah satu solusi yang paling tepat adalah pelaksanaan pembelajaran dengan sistem luar jaringan (luring). Luring merupakan sebuah akronim dari luar jaringan yang bermkna tidak menggunakan jaringan internet. Menurut (Malyana, 2020) kegiatan belajar mengajar dengan sistem luring dapat dilakukan dengan belajar melalu buku dan pertemuan tatap muka secara langsung. Selain itu, Ada beberapa alternative yang dapat dilakukan dalam proses belajar luring seperti menggunakan modul belajar, lembar kerja, radio, televisi, bahan ajar cetak, serta media belajar dari benda-benda yang ada di lingkungan sekitar. (Kemendikbud, 2020) Strategi ini menjadi pilihan tepat untuk proses pembelajaran di daerah 3T (Dormalin et al., 2020).

Salah satu sekolah yang berada di daerah 3T yaitu SMP Negeri 7 Budong-budong, Mamuju Tengah. Seperti halnya sekolah lain yang berada di daerah $3 \mathrm{~T}$ dalam menghadapi penyebaran Covid-19, SMP Negeri 7 Budongbudong harus menempuh berbagai cara agar para siswa mendapat layanan pendidikan selama masa Covid-19, termasuk proses pembelajaran luar jaringan (luring). Ada beberapa cara yang dilakukan oleh para guru dalam sistem pembelajaran luar jaringan seperti, menyiapkan modul dan Lembar Kerja Siswa (LKS) kemudian diberikan kepada siswa agar mereka mengerjakannya secara mandiri di rumah. Namun pada pelaksanaan pola pembelajaran seperti ini dinilai kurang efektif. Hal ini dikarenakan beberapa siswa terkadang tidak mengambil LKS di sekolah, bahkan ada di antara mereka yang telah mengambil LKS tersebut namun tidak mengumpulkannya sesuai waktu yang ditentukan. Sementara itu, kurangnya pendampingan orangtua dalam proses pembimbingan anaknya untuk belajar mandiri di rumah semakin membuat pola ini makin kurang optimal. 
Dengan berbagai pertimbangan, akhirnya pihak SMP Negeri 7 Budong-budong menerapkan Cluster Learning System dalam pembelajaran di masa Covid-19. Cluster learning system merupakan proses pembelajaran yang dilakukan pada kelompok peserta didik pada lokasi tertentu. Lokasi cluster peserta didik ditentukan dengan jumlah mayoritas peserta didik dalam satu daerah. Hal ini dikuatkan oleh pendapat (Fatkhurrahman, 2017), ia mengungkapkan bahwa sistem pembagian kelompok dalam pembelajaran cluster diatur sesuai dengan lokasi tempat tinggal peserta didik. Pola ini dilakukan agar para pendidik mudah menjangkau peserta didik. Strategi ini dinilai alternative paling baik oleh beberapa guru dan siswa karena mampu memberikan nuansa tatap muka sepeti biasanya namun tetap memperhatikan protokol kesehatan sesuai dengan kondisi selama masa pandemic Covid-19.

Untuk itu, penelitian ini bertujuan untuk mendeskripsikan penerapan Cluster Learning System dalam pembelajaran di masa pandemi Covid-19 di SMP Negeri 7 Budong-budong..

\section{METODE}

In the section, please explain clearly how to conduct your research in order to: (1) enable readers to evaluate the work performed and (2) permit others to replicate the research. The author must describe exactly Jenis penelitian ini adalah kualitatif. Hal ini bertujuan untuk mendapatkan gambaran yang jelas tentang penerapan Cluster Learning System dalam proses pembelajaran di masa Covid-19 di daerah 3T. Secara umum penelitian deskriptif merupakan jenis penelitian yang memberikan gambaran tentang gejala, fakta, kejadian secara akurat dan sistematis. (Hardani et al., 2020)

Dalam penelitian ini, ada dua sumber data yang digunakan yaitu sumber primer dan sekunder. Sehingga adapun metode pengumpulan data yang dilakukan yaitu observasi, wawancara mendalam serta dokumentasi. Menurut (Suyitno, 2018) mengungkapkan bahwa pada umumnya teknik pengumpulan data dalam penelitian kualitatif bersifat tentative. Diharapkan teknik pengumpulan data ini mampu memberikan informasi yang menyuluruh terhadap masalah yang diteliti.

Sementara itu, data yang telah terkumpul, selanjutnya dilakukan proses analisis. Analisis data merupakan proses mencari dan menyusun data yang telah dikumpulkan kemudian diklasifikasikan mana data yang dapat digunakan dan mana data yang tidak digunakan selanjutnya menarik kesimpulan (Shidiq \& Choiri, 2019). Untuk itu, proses analisis data yang digunakan dalam penelitian ini yaitu model Miles dan Huberman, yaitu melalui tahapan reduksi data, penyajian data dan penarikan kesimpulan.

\section{TEORI DAN PEMBAHASAN}

Menurut data yang telah dikumpulkan, SMP Negeri 7 Budong-budong didirikan pada tahun 2011. Saat itu SMP Negeri 7 Budongbudong masih berstatus Sekolah Satu Atap (SATAP) di awal keberadaannya, saat ini SMP Negeri 7 Budong-budong memiliki gedung sendiri yang berdiri di atas tanah hibah seluas $10.000 \mathrm{~m}^{2}$ dan berlokasi di Jalan Pendidikan Desa Pasapa, Kec. Budong-budong Kab. Mamuju Tengah, Prov. Sulawesi Barat.

Tahun pelajaran 2020/2021 SMP Negeri 7 Budong-budong membina sebanyak 65 peserta didik yang terbagi ke dalam 3 rombongan belajar dengan masing-masing 1 rombongan belajar untuk kelas VII, 1 rombongan belajar untuk kelas VIII dan 1 rombongan belajar untuk kelas IX. Setiap ruang kelas menampung rata-rata sebanyak 19 peserta didik.

SMP Negeri 7 Budong-budong kini memiliki guru sebanyak 10 orang yang berstatus sebagai pegawai negeri sipil, 1 tenaga administrasi dengan status PNS dan 5 orang guru sebagai tenaga kontrak dan 3 orang guru honorer.

Di masa pagebluk Covid-19, SMP Negeri 7 Budong-budong sebagai salah satu lembaga pendidikan formal tetap memberikan layanan pendidikan sesuai dengan arahan dari kementrian pendidikan dan Dinas Pendidikan dan Kebudayaan Kab. Mamuju Tengah. Namun dengan melihat situasi yang sulit yaitu kurangnya sarana dan prasarana untuk melakukan pembelajaran dalam jaringan (daring). Maka pihak sekolah harus mencari 
alternative lain. Hal ini dikarenakan letak geografis SMP Negeri 7 Budong-budong yang termasuk ke dalam wilayah $3 \mathrm{~T}$.

Ada beberapa strategi yang dilakukan oleh SMP Negeri 7 Budong-budong dalam melakukan proses belajar mengajar di masa penyebaran Covid-19. Awalnya pendidik di SMP Negeri 7 Budong-budong menggunakan aplikasi messenger dan whatsapp untuk melakukan interaksi kepada peserta didik. Karena dirasa banyak kendala terutama jaringan internet bahkan kebanyakan siswa tidak memiliki smartphone. Akhirnya para guru menggunakan sistem modul dan Lembar Kerja Siswa (LKS), hal ini berjalan beberapa pekan. Namun setelah dievaluasi metode seperti ini dirasa masih kurang efektif. Maka SMP Negeri 7 Budong-budong menggunakan cluster learning system. Cluster learning system merupakan proses pembelajaran yang dilakukan pada kelompok peserta didik di lokasi-lokasi yang telah ditentukan.

Kegiatan pembelajaran dengan Cluster Learning System yang dilakukan oleh SMP Negeri 7 Budong-budong dibagi kedalam beberapa tahap yaitu:

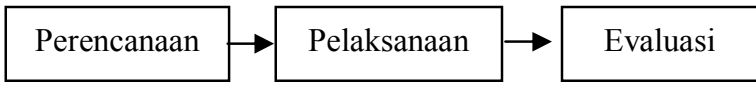

\section{Perencanaan}

Suatu kegiatan dalam sebuah organisasi ataupun lembaga sangat tergantung sejauh mana perencanaan yang dilakukan. Hal ini dikuatkan oleh pendapat (Utami \& Hasanah, 2013) menurutnya perencanaan termasuk salah satu tahapan manajamen yang paling awal, selain itu berperan sebagai hal yang paling dasar dari beberapa fungsi manajemen. Perencanaan merupakan suatu proses berlanjut yang berupa kegiatan-kegiatan perumusan masalah, diagnosa kebutuhan, pemilihan data, pengumpulan data, faktor penunjang dan pengahmbat, pilihan pemecahan masalah, penentuan jadwal kegiatan, monitoring, evaluasi, refleksi serta pengambilan keputusan(Syaefudin, S.U. \& Syamsudin, 2005)

Berdasarkan hasil wawancara, pada tahap perencanaan Cluster Learning System yang telah diimplementasikan oleh SMP
Negeri 7 Budong-budong ada beberapa kegiatan yang dilakukan oleh pihak sekolah yaitu melakukan koordinasi dengan dinas pendidikan, rapat dewan guru, pembuatan jadwal pembelajaran, pembagian kelompok siswa, penentuan tempat belajar serta tahapan sosialisasi kepada siswa dan masyarakat.

Pada kegiatan koordinasi, kepala sekolah berkomunikasi dengan pengawas sekolah serta dinas pendidikan Kab. Mamuju Tengah. Hal ini dilakukan agar setiap keputusan yang dilakukan oleh pihak sekolah tidak bertentangan dengan kebijakan yang telah ditetapkan oleh Dinas Pendidikan dan Kebudayaan Kab. Mamuju Tengah. Dalam arahannya, Dinas Pendidikan Kab. Mamuju Tengah menyerahkan sepenuhnya kepada pihak sekolah untuk menyesuaikan pelaksanaan pembelajaran di masa pandemi Covid-19. Lebih jauh Dinas Pendidikan Dan Kebudayaan Kab. Mamuju Tengah memberikan beberapa alternative kepada lembaga sekolah. Jika akses jaringan memungkinkan dan para siswa memiliki fasilitas yang diperlukan seperti smartphone ataupun komputer. Maka sekolah bisa mengadakan pembelajaran jarak jauh dengan sistem dalam jaringan (daring). Namun, bagi sekolah yang memiliki kendala dalam pembelajaran via daring (online) tersebut. Maka sekolah dapat memilih melakukan pembelajaran dengan sistem luar jaringan (luring).

Sistem pembelajaran luar jaringan yang diterapkan oleh SMP Negeri 7 Budong-budong menggunakan sistem cluster. Karena sebagian besar peserta didik tidak memiliki smartphone ataupun computer. Di samping itu, letak geografis SMP Negeri 7 Budong-budong yang berada di daerah terpencil membuat akses jaringan belum maksimal. Hal ini senada dengan pendapat (Rigianti, 2020) menurutnya ada beberapa kendala yang dialami oleh pendidik dalam melakukan proses belajar mengajar via daring seperti belum menguasai aplikasi pembelajaran yang ada, jaringan internet yang terbatas, pengelolaan pembelajaran, proses penilaian serta pengawasan.

Selain melakukan koordinasi dengan beberapa pihak. SMP Negeri 7 Budongbudong juga melakukan rapat dan musyawarah 
antara pihak kepala sekolah dan dewan guru. Pada tahapan ini kepala sekolah mengumpulkan para guru untuk bermusyawarah tentang evaluasi dan tindak lanjut sistem pembelajaran di masa Covid-19 yang sebelumnya telah dilakukan. Selain itu, dalam rapat ini juga, dewan guru sepakat untuk melaksanakan pembelajaran dengan pola Cluster Learning System sebagai tindak lanjut hasil evaluasi pembelajaran di masa pandemi.

Pada rapat perencanaan ini pula, disusun pembagian kelompok siswa menjadi 5 kelompok. Pembagian kelompok ini disesuaikan dengan letak domisili peserta didik. Selanjutnya pihak sekolah menetapkan lokasi pembelajaran di tiap kelompok (cluster). Sehingga para peserta didik akan mendapatkan layanan pendidikan di lokasi tersebut. Pembagian lokasi untuk peserta didik dapat dilihat dalam tabel I, di bawah ini

Tabel 1. Pembagian lokasi dan jumlah peserta didik

\begin{tabular}{llc}
\hline Kel & \multicolumn{1}{c}{ Lokasi } & $\begin{array}{c}\text { Jumlah } \\
\text { peserta } \\
\text { didik }\end{array}$ \\
\hline I & Dusun Pasapa, Desa Pasapa & 11 \\
II & Dusun Pasapa, Desa Pasapa & 10 \\
III & Dusun Pasapa, Desa Pasapa & 10 \\
IV & Dusun Lereng Gunung, Desa & 17 \\
& Pasapa & 17 \\
V & Dusun Talodo, Desa Pasapa & 17 \\
\hline
\end{tabular}

Dari tabel tersebut terlihat bahwa untuk kelompok I, II dan III berada di Dusun Pasapa, jumlah total peserta didik yang belajar di Dusun Pasapa berjumlah 31 orang. Sementara itu untuk cluster IV yang berlokasi di Dusun Lereng Gunung berjumlah 17 orang. Hal serupa juga terlihat di Dusun Talodo sebagai cluster $\mathrm{V}$, peserta didik yang belajar di lokasi tersebut berjumlah 17 orang.

Setelah pihak sekolah melakukan koordinasi dan juga rapat. Maka tahapan selanjutnya adalah tahapan sosialisasi. Tahapan sosialisasi ini memegang peranan penting dalam hal menyebarkan informasi dan kebijakan baru. Menurut (Yunus, 2006) Aktivitas sosialisasi merupakan proses penyebarluasan informasi dengan penjelasan yang lebih operasional dan mudah dipahami oleh masyarakat umum.
Ada beberapa cara yang dilakukan oleh pihak sekolah untuk tahapan ini. Pertama, pihak sekolah menempel pengumuman di sekolah, mulai dari informasi tentang pembagian kelompok siswa, informasi tentang lokasi pembelajaran (cluster), serta jadwal pelajaran yang menyesuaikan kondisi di masa pandemi Covid-19.

Kedua, pihak sekolah menyampaikan secara langsung kepada peserta didik, orangtua, ataupun wali yang ditemui di jalan atau berdekatan rumah dengan guru SMP Negeri 7 Budong-budong. Hal ini dilakukan karena komunikasi via handphone tidak efektif karena beberapa orangtua tidak memiliki handphone. Ketiga, menyampaikan melalui gereja dan masjid di Desa Pasapa, ketika ada ibadah di gereja maka pihak pendeta ataupun panitia ibadah menyampaikannya kepada jemaat gereja. Sama halnya ketika ada sholat jumat di masjid, pihak dari panitia masjid menyampaikannya ke jamaah sholat jumat terkait kebijakan pembelajaran di masa Covid19 di SMP Negeri 7 Budong-budong. Sehingga ketiga cara yang dilakukan oleh pihak SMP Negeri 7 Budong-budong dalam menyebarkan informasi ini sangat efektif, terbukti semua peserta didik mengetahui tentang aturan baru yang telah diterapkan oleh pihak sekolah.

\section{Pelaksanaan}

Pada tahap pelaksanaan, guru SMP Negeri 7 Budong-budong mendatangi lokasi (cluster) yang telah ditentukan oleh sekolah dengan merujuk pada jadwal yang telah disusun sebelumnya, begitu juga dengan para peserta didik yang harus mengikuti proses pembelajaran sesuai cluster yang telah ditentukan.

Tentunya dalam proses pembelajaran dengan sistem seperti ini, tidak akan sama dengan kondisi normal. Ada beberapa hal penyesuaian yang dilakukan oleh pihak sekolah seperti muatan mata pelajaran. Mata pelajaran lebih disederhanakan mulai dari waktu dan materinya. Hal ini agar para siswa tetap mendapat materi pembelajaran yang lebih subtansi meskipun durasi waktunya lebih sedikit dari biasanya. Contohnya untuk mata pelajaran bahasa Indonesia yang awalnya 6 jam pelajaran setiap minggu. Namun untuk 
kondisi di masa pandemi durasi waktu untuk mata pelajaran bahasa Indonesia menjadi 1 jam pelajaran. Hal ini juga berlaku untuk semua mata pelajaran. Melihat jadwal yang telah disusun oleh SMP Negeri 7 Budong-budong, pembelajaran dimulai pada pukul 08.00 11.00. Sehingga setiap kelompok (cluster) peserta didik dalam sehari mendapatkan 3 mata pelajaran dengan durasi tiap mata pelajaran adalah 50 menit. Disamping itu, pembelajaran yang awalnya 6 hari sepekan, di masa pandemic hanya 2 hari yaitu senin dan kamis.

Ada 5 lokasi yang dijadikan tempat untuk proses belajar mengajar yaitu, Cluster I, II, III berada di balai desa Pasapa, Cluster IV di Dusun Talodo, Cluster V berada di dusun Lereng Gunung. Di tempat inilah proses belajar mengajar dilakukan. Setiap tempat yang telah ditentukan, rata-rata siswa yang mengikuti pelajaran di tempat tersebut $13-15$ peserta didik.

Dalam proses pembelajaran di tiap cluster, para guru membagi siswa sesuai dengan jenjang kelasnya. Hal ini dilakukan karena komposisi peserta didik dari tiap cluster terdiri dari 3 kelas. Sehingga untuk memaksimalkan penyampaian materi. Guru harus membagi peserta didik sesuai jenjang kelasnya. Menurut (Utami \& Hasanah, 2013)proses belajar mengajar dengan pola merangkap kelas merupakan kompetensi yang sebaiknya dimiliki oleh pendidik untuk memberikan layanan pendidikan tiap jenjang kelas.

Proses belajar mengajar juga tak jauh beda dari kondisi pembelajaran normal. Dalam kondisi seperti ini, guru memiliki peranan yang sangat penting. Guru diharapkan mampu menjalankan pendidikan dan pembelajaran, selain itu, guru juga diharapkan mampu mengorganisasikan lingkungan belajar (Wahyono et al., 2020). Pada kegiatan belajar mengajar, Guru tetap mengacu pada Rencana Pelaksanaan Pembelajaran (RPP) yang telah disusun sebelumnya. Guru memulai pembelajaran dengan kegiatan awal, kegiatan inti dan kegiatan akhir. (Zein, 2016) mengungkapkan bahwa di masa new normal, mutu proses belajar mengajar sangat ditentukan oleh kualitas pendidik. Sementara itu, pendidik dianggap berkualitas jika dia menyiapkan perencanaan pembelajarannya. Namun tentunya RPP yang disusun oleh guru tetap menyesuaikan durasi yang telah ditentukan yaitu 50 menit. Sehingga proses belajar mengajar dengan menggunakan learning cluster method tidak mengalami kendala.

Selain itu, pelaksanaan learning cluster method yang dilakukan oleh SMP Negeri 7 Budong-budong tetap mematuhi protokol kesehatan. Hal ini terlihat dari penggunaan masker untuk pendidik dan peserta didik selama proses belajar mengajar berlangsung. Sebelumnya, SMP Negeri 7 Budong-budong melakukan pengadaan masker bagi pendidik dan peserta didik dengan memanfaatkan anggaran Bantuan Operasional Sekolah (BOS)

Selain itu, pada proses pembelajaran, pendidik dan peserta didik juga tetap menjaga jarak yang aman agar penularan Covid-19 dapat dicegah. Ditambah lagi, pihak sekolah menyediakan tempat cuci tangan serta hand sanitizer di tiap cluster.

Semua upaya ini dilakukan oleh pihak SMP Negeri 7 Budong-budong untuk mendukung pencegahan penyebaran Covid-19 yang telah digalakkan oleh pemerintah Indonesia. Di samping itu, agar kesehatan para pendidik dan peserta didik tetap terjamin selama proses belajar mengajar tatap muka dengan sistem cluster.

\section{Evaluasi}

Pelaksanaan proses pembelajaran baik melalui daring maupun luring selama masa Covid-19 tentunya memberikan tantangan tersendiri bagi pendidik dan peserta didik. Hal ini juga terlihat dalam implementasi Cluster Learning System yang telah dijalankan oleh SMP Negeri 7 Budong-budong. Terdapat beberapa kelebihan dan kekurangan yang terlihat dalam pelaksanaannya.

Pelaksanaan Cluster Learning System sangat membantu peserta didik dalam memahami materi pembelajaran. Hal ini dikarenakan peserta didik dapat berinteraksi langsung dengan pendidik. Sehingga mereka mendapatkan penjelasan tentang materi mata pelajaran secara tatap muka dengan gurunya. Selain itu, jika ada hal-hal yang kurang dipahami oleh peserta didik, mereka bisa menyampaikan secara langsung kepada guru. 
Pembelajaran dinilai efektif jika terjadi interaksi dari berbagai arah, mulai dari interaksi antara guru-siswa atau sebaliknya siswa ke guru, interaksi antara siswa yang satu ke siswa yang lain, interaksi antara siswa dan sumber belajar, serta terjalin interaksi antara siswa dan lingkungan belajarnya (Nurdyansyah \& Fahyuni, 2016).

Di samping itu, suasana pembelajaran secara tatap muka, membuat para siswa dapat berdiskusi dengan temannya, dapat saling bercengkrama sehingga tercipta iklim belajar yang baik. Secara tidak langsung, kondisi ini membuat para siswa tidak bosan dan juga menjadi lebih semangat untuk belajar di masa pandemi Covid-19.

Pola pembelajaran ini pula menjadi sarana bagi pendidik untuk mensosialisasikan tentang pola hidup sehat serta pendidikan karakter. Hal itu dibuktikan disetiap awal dan akhir pembelajaran, para guru selalu mengingatkan para peserta didik untuk rajin mencuci tangan serta menyampaikan kepada petugas kesehatan jika terjadi gejala-gejala yang diduga ciri-ciri virus Covid-19.

Kelebihan lain dari Cluster Learning System yaitu tidak memerlukan media gawai (smartphone ataupun computer) dalam proses kegiatan belajar mengajar. Seperti yang kita ketahui bersama bahwa kondisi di daerah $3 \mathrm{~T}$ sangat tidak mendukung adanya pembelajaran secara online

Meskipun Cluster Learning System memiliki berbagai kelebihan. Namun dalam implementasinya di SMP Negeri 7 Budongbudong ada beberapa hal yang perlu diperbaiki. Pertama, Guru harus menguasai jalannya proses pembelajaran. Hal ini dikarenakan dalam 1 cluster, peserta didik yang hadir terdiri dari 3 kelas, mulai dari kelas VII hingga kelas IX, sehingga jika guru tidak mampu menguasai kelas, maka peserta didik akan ribut dan saling mengganggu.

Kedua, kurangnya sarana pembelajaran, sehingga para siswa harus duduk di lantai. Selain itu pada tiap cluster tidak terdapat papan tulis. Jadi guru hanya melakukan pembelajaran secara konvensional. Hal ini dapat dimaklumi lantaran peserta didik belajar tidak di sekolah melainkan di rumah atau balai desa. Sehingga terkadang para peserta didik jika duduk terlalu lama di lantai, mereka merasa tidak nyaman.
Menurut (Rachman, 2020) pada masa pandemi Covid-19 ini, pembelajaran yang biasanya terjadi di kelas tidak dapat lagi dilakukan, untuk itu harus dilakukan di rumah, namun tentunya harus didesain dengan baik agar proses belajar mengajar dapat optimal.

Ketiga, fokus peserta didik rentan terganggu. Hal ini dikarenakan lokasi cluster berada dekat dengan pemukiman penduduk, terkadang para penduduk yang sedang melewati cluster ikut memperhatikan kegiatan belajar mengajar, bahkan beberapa diantaranya mengajak bicara guru ataupun peserta didik. Sehingga peserta didik yang tengah asyik belajar, konsentrasinya tertuju pada suara penduduk tersebut, sehingga hal ini secara tidak langsung cukup mengganggu proses belajar mengajar.

Keempat, Guru harus mampu mengatur waktu dengan baik, hal ini dikarenakan lokasi cluster satu dengan lainnya berjauhan. Sehingga terkadang para guru, jika selesai mengajar di cluster satu, mereka harus segera menuju ke cluster yang lain dan kondisi ini cukup menyita waktu dan tenaga para guru. Misalnya salah seorang guru pada jam pertama mengajar di cluster I di Dusun Pasapa, namun pada jam berikutnya harus mengajar di cluster V yaitu di Dusun Talodo. Sehingga sang guru setelah selesai mengajar di dusun pasapa, dia harus secepatnya menuju dusun Talodo. Hal ini dilakukan agar para peserta didik di cluster $\mathrm{V}$ tidak berkeliaran atau malah pulang ke rumahnya masing-masing.

\section{KESIMPULAN}

SMP Negeri 7 Budong-budong di masa pandemi Covid-19 telah melakukan berbagai cara dalam memberikan proses layanan pendidikan untuk peserta didik. Dimulai dengan cara pembelajaran menggunakan aplikasi messenger dan whatsapp, pembelajaran dengan sistem pembagian modul dan LKS, dan pola terakhir menggunakan Cluster Learning System. Dari beberapa metode pembelajaran yang digunakan. Cluster Learning System terlihat cukup efektif dalam proses belajar mengajar di daerah $3 \mathrm{~T}$ selama masa pandemi Covid-19. Khususnya di SMP Negeri 7 Budong-budong

Dalam penerapan Cluster Learning System, SMP Negeri 7 Budong-budong 
mengkategorikan menjadi 3 tahapan, dimulai dari tahap perencanaan, tahap pelaksanaan serta tahap evaluasi. Pada tahap perencanaan ada beberapa hal yang dilakukan oleh pihak sekolah yaitu, melakukan koordinasi, rapat, serta sosialisasi. Pada tahap pelaksanaan para guru dan peserta didik mengikuti jadwal yang telah ditentukan oleh pihak sekolah.

Di tahap evaluasi terlihat bahwa ada beberapa kelebihan dalam pelaksanaan Cluster Learning System di SMP Negeri 7 Budongbudong. Seperti memudahkan siswa dalam memahami pembelajaran, menjadi sarana pembentukan karakter dan wadah sosialisasi tentang pencegahan virus Covid-19.

Namun di sisi lain, ada juga beberapa kelemahan yang perlu diperbaiki agar sistem pembelajaran ini lebih optimal. Seperti manajemen waktu yang harus diperhatikan, sangat rentang terganggu dalam proses belajar mengajar, minimnya sarana belajar seperti tempat duduk ataupun papan tulis.

\section{REFERENSI}

Chen, N., Zhou, M., Dong, X., Qu, J., Gong, F., Han, Y., Qiu, Y., Wang, J., Liu, Y., Wei, Y., Xia, J., Yu, T., Zhang, X., \& Zhang, L. (2020). Epidemiological and Clinical Characteristics of 99 Cases of 2019 Novel Coronavirus Pneumonia in Wuhan, China: a descriptive study. The Lancet, 395(10223), 507-513. https://doi.org/10.1016/S01406736(20)30211-7

Chih-Cheng Lai , Tzu-Ping Shih, Wen-Chien Ko, Hung-Jen Tang, P.-R. H. (2020). Severe Acute Respiratory Syndrome Coronavirus 2 (SARS-CoV-2) and Coronavirus Disease-2019 (COVID-19): The Epidemic and the Challenges. International Journal of Antimicrobial Agents, S0889-1591(January), 30511-0.

Dormalin, T., Liufeto, M. C., \& Cornelis, Y. Y. (2020). Implementasi Belajar Dari Rumah (BDR) bagi Tenaga Pendidik Untuk Meningkatkan Profesionalitas Mengajar di daerah Terpencil. Prosiding Hasil Pengabdian Kepada Masyarakat, Hapemas 2, 359-367. http://conference.um.ac.id/index.php/hape mas/article/view/269
Fatkhurrahman, B. Y. (2017). Sistem Pembagian Kelompok Belajar Siswa Menggunakan Metode K-Means Clustering Di Sd Negeri 1 Ngebong Kabupaten Tulungagung Bagus. 01(08).

Hardani, Nur Hikmatul Auliya, Andriani, H., Fardani, R. A., Ustiawaty, J., Utami, E. F., Sukmana, D. J., \& Istiqomah, R. R. (2020). Metode Penelitian Kualitatif \& Kuantitatif (A. Husnu Abadi, A.Md. (ed.)). CV. Pustaka Ilmu.

Kemendikbud. (2020a). Pelaksanaan Kebijakan Pendidikan Dalam Masa Darurat Penyebaran Coronavirus Disease (COVID-19). https://www.kemdikbud.go.id/main/blog/ 2020/03/se-mendikbud-pelaksanaankebijakan-pendidikan-dalam-masadarurat-penyebaran-covid19

Kemendikbud, pengelola web. (2020b). Pedoman Penyelenggaraan Belajar dari Rumah.

https://www.kemdikbud.go.id/main/blog/ 2020/05/kemendikbud-terbitkanpedoman-penyelenggaraan-belajar-darirumah

Kurniasari, A., Pribowo, F. S. P., \& Putra, D. A. (2020). Analisis Efektivitas Pelaksanaan Belajar dari Rumah (Bdr) Selama Pandemi Covid-19. Jurnal Review Pendidikan Dasar: Jurnal Kajian Pendidikan dan Hasil Penelitian, 6(3), 18.

Malyana, A. (2020). Pelaksanaan Pembelajaran Daring dan Luring dengan Metode Bimbingan Berkelanjutan dada Guru Sekolah Dasar di Teluk Betung Utara Bandar Lampung. Pedagogia: Jurnal Ilmiah Pendidikan Dasar Indonesia, 2(1), 67-76. https://doi.org/10.52217/pedagogia.v2i1.6 40

Nurdyansyah, \& Fahyuni, E. F. (2016). Inovasi Model Pembelajaran Sesuai Kurikulum 2013. In Nizmania Learning Center.

Rachman, S. A. (2020). Pentingnya Penyediaan Lingkungan Belajar yang Kondusif bagi Anak Usia Dini Berbasis Kunjungan Belajar di Masa New Normal. Jrnal Ilmiah Wahana Pendidikan, 6(3), 480-487.

Rigianti, H. A. (2020). Kendala Pembelajaran 
Daring Guru Sekolah Dasar di Kabupaten Banjarnegara. Elementary School, 7, 297302.

Selvi Loviana, W. N. B. (2020). Dampak Pandemi Covid-19 Pada Kesiapan Pembelajaran Tadris Matematika Iain Metro Lampung. Journal Epsilon, 2(1), 62-70.

Shidiq, U., \& Choiri, M. (2019). Metode Penelitian Kualitatif di Bidang Pendidikan. In Journal of Chemical Information and Modeling (Vol. 53, Issue 9).

http://repository.iainponorogo.ac.id/484/1

/Metode Penelitian Kualitatif di Bidang Pendidikan.

Suyitno. (2018). Metode Penelitian Kualitatif: Konsep, Prinsip dan Operasionalnya.

Syaefudin, S.U. \& Syamsudin, M. A. (2005). Perencanaan Pendidikan: suatu pendekatan komprehensif. Remaja Rosdakarya.

Utami, I. H., \& Hasanah, A. (2013). Kompetensi Profesional Guru dalam Penerapan Pembelajaran Tematik Di Sd Negeri Maguwoharjo 1 Yogyakarta. c, 121-139.

Wahyono, P., Husamah, H., \& Budi, A. S.
(2020). Guru profesional di Masa Pandemi COVID-19: Review Implementasi, Tantangan, dan Solusi Pembelajaran Daring. Jurnal Pendidikan Profesi Guru, 1(1), 51-65. http://ejournal.umm.ac.id/index.php/jppg/ article/view/12462

Yulianingsih, W., Suhanadji, S., Nugroho, R., \& Mustakim, M. (2020). Keterlibatan Orangtua dalam Pendampingan Belajar Anak Selama Masa Pandemi Covid-19. Jurnal Obsesi : Jurnal Pendidikan Anak Usia Dini, 5(2), 1138-1150. https://doi.org/10.31004/obsesi.v5i2.740

Yunus, M. (2006). Kebijakan kemitraan pendidikan kejuruan. Pustaka Kayutangan.

Zein, M. (2016). Peran Guru dalam Pengembangan Pembelajaran. Jurnal Inspiratif Pendidikan, 5(2), 274-285. http://103.55.216.56/index.php/InspiratifPendidikan/article/view/3480 